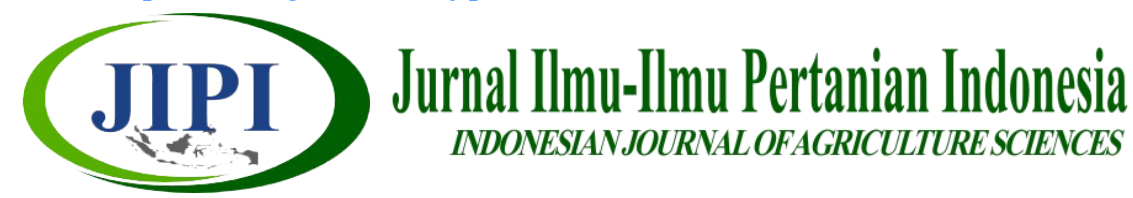

\title{
DAMPAK APLIKASI FLY ASH DARI PEMBANGKIT LISTRIK DI PT. GREAT GIANT PINEAPPLE-LAMPUNG TERHADAP AKTIVITAS BIOLOGI TANAH DI LAHAN MARGINAL
}

\author{
Nurleni Kurniawati $^{1 *}$ dan Priyadi ${ }^{1}$ \\ ${ }^{1}$ Program Studi Agroekoteknologi STIPER Dharma Wacana, Metro, Indonesia \\ *Corresponding Author:nurleni_k@yahoo.com
}

\begin{abstract}
[EFFECT OF FLY ASH APPLICATION FROM POWER PLANT OF PT. GREAT GIANT PINEAPPLE ON SOIL BIOLOGYCAL ACTIVTY IN MARGINAL LAND]. Fly ash is a coal combustion waste containing nutrients that can be used to improve the soil fertility. The waste continues to increase but its handling is still limited because it is still classified as hazardous and toxic waste (B3). This study aims to determine the soil biological activity due to the application of fly ash and cow manure on marginal soils. The study was conducted using a completely randomized block design arranged factorial. The first factor is the dosage level of fly ash (F), namely $0 \mathrm{~g} / \mathrm{pot}(0 \mathrm{ton} / \mathrm{ha}), 75 \mathrm{~g} / \mathrm{pot}$ (50 ton/ha), $150 \mathrm{~g} / \operatorname{pot}(100 \mathrm{ton} / \mathrm{ha})$, and $225 \mathrm{~g} / \operatorname{pot}(150 \mathrm{ton} / \mathrm{ha})$ and the second factor is the dose of cow manure with three levels, namely $15 \mathrm{~g} / \operatorname{pot}(10 \mathrm{ton} / \mathrm{ha}), 30 \mathrm{~g} / \operatorname{pot}(20 \mathrm{ton} / \mathrm{ha})$, and $45 \mathrm{~g} / \operatorname{pot}(30 \mathrm{ton} / \mathrm{ha})$. The observation parameters were (total population of fungi, bacteria, and soil respiration). The results showed that the addition of fly ash at various doses affected the soil biological activity by increasing the population of fungi, bacteria and soil respiration. The highest population of microorganisms was fungi, which was $17.8 \times 107 \log \mathrm{CFU} / \mathrm{g}$, bacteria 13.7 x $105 \log$ $\mathrm{CFU} / \mathrm{g}$, while the highest soil respiration was $54.53 \mathrm{mg} \mathrm{CO}$ at a dose of 100 ton/ha fly ash. In addition, the application of cow manure at a dose of 10, 20,30 ton/ha did not affect observed variables.
\end{abstract}

Keyword: fly ash, marginal land, soil biological activity, soil respiration,

\begin{abstract}
ABSTRAK
Fly ash merupakan limbah pembakaran batu bara dengan kandungan unsur hara yang dapat digunakan untuk memperbaiki tanah. Limbah tersebut terus meningkat tetapi penanganannya masih terbatas karena masih digolongkan limbah bahan berbahaya dan beracun (B3). Penelitian ini bertujuan untuk mengetahui aktivitas biologi tanah akibat penerapan fly ash dan pupuk kandang sapi pada tanah marginal. Penelitian dilakukan dengan menggunakan Rancangan Acak Kelompok Lengkap yang disusun faktorial. Faktor pertama adalah level dosis fly ash $(\mathrm{F})$ yaitu $0 \mathrm{~g} / \operatorname{pot}(0$ ton/ha $), 75 \mathrm{~g} /$ pot $(50 \mathrm{ton} / \mathrm{ha}), 150 \mathrm{~g} / \operatorname{pot}(100 \mathrm{ton} / \mathrm{ha})$, dan $225 \mathrm{~g} / \operatorname{pot}(150 \mathrm{ton} / \mathrm{ha})$ dan faktor kedua adalah dosis pupuk kandang sapi dengan tiga taraf yaitu $15 \mathrm{~g} /$ pot (10 ton/ha), $30 \mathrm{~g} /$ pot (20 ton/ha), dan $45 \mathrm{~g} /$ pot (30 ton/ha). Variabel pengamatan berupa (total fungi, total bakteri, dan respirasi tanah). Hasil penelitian menunjukkan bahwa penambahan fly ash berbagai dosis mempengaruhi aktivitas biologi tanah dengan ditandai peningkatan populasi fungi, bakteri, dan respirasi tanah. Populasi mikroorganisme tertinggi fungi yaitu $17,8 \times 107$ Log CFU/g, bakteri 13,7 x $105 \mathrm{Log}$ CFU/g sedangkan respirasi tanah tertinggi yaitu 54,53 $\mathrm{mg} \mathrm{CO}_{2}$ pada dosis fly ash 100 ton/ha. Selain itu pada pemberian pupuk kandang sapi dengan dosis 10, 20, 30 ton/ha relatif sama pada semua peubah yang diamati
\end{abstract}

Kata kunci: aktivitas biologi tanah, bakteri, fungi, fly ash, respirasi tanah 


\section{PENDAHULUAN}

Batu bara merupakan sumber bahan bakar yang lebih murah dibandingkan sumber bahan bakar lainnya seperti gas, surya matahari dan lainnya. Penggunaan batu bara pada sektor industri menghasilkan limbah berupa abu dasar (bottom ash) dan abu terbang (fly ash). Fly ash merupakan residu akhir dari pembakaran batubara yang mengandung mineral yang tidak sepenuhnya terbakar (Basu et al., 2009). Limbah tersebut dihasilkan oleh industri besar yang setiap tahunnya semakin meningkat, tetapi penanganannya masih terbatas dan bahkan menimbulkan masalah lingkungan seperti pencemaran udara, perairan dan penurunan kualitas ekosistem. Fly ash bila ditimbun akan menghasilkan gas metana $\left(\mathrm{CH}_{4}\right)$ yang dapat terbakar atau meledak dengan sendirinya (self burning dan self exploding) sehingga digolongkan ke dalam limbah B3 (Bahan Beracun Berbahaya) (Kementrian LHK, 2020). Dengan demikian perlu adanya penelitianpenelitian lebih lanjut mengenai fly ash.

Fly ash telah dimanfaatkan oleh berbagai negara dan di berbagai sektor, seperti sektor pembangunan dan pertanian pada negara jepang (Aggarwal et al., 2009). Hal ini berkaitan dengan kandungan yang terdapat pada fly ash. Penelitian Basu et al. (2009) menunjukkan bahwa limbah batu bara berupa fly ash mengandung berbagai unsur hara makro dan mikro, seperti $\mathrm{P}, \mathrm{K}, \mathrm{Ca}, \mathrm{Mg}, \mathrm{S}, \mathrm{Fe}, \mathrm{Mn}, \mathrm{Zn}, \mathrm{Cu}, \mathrm{Co}, \mathrm{B}$ dan Mo. Fly ash juga dilaporkan dapat memperbaiki sifat fisik dan kimia tanah. Kohli \& Goyal (2010) menyatakan bahwa penggunaan fly ash dapat meningkatkan tingkat $\mathrm{P}$ dan diketahui juga di dalam tanaman bahwa konsentrasi $\mathrm{Cd}, \mathrm{Cu}, \mathrm{Fe}, \mathrm{Mn}, \mathrm{Mg}, \mathrm{Ni}, \mathrm{Pb}$, dan $\mathrm{Zn}$ yang sangat rendah dan memenuhi syarat untuk konsumsi.

Pemberian fly ash mengandung $\mathrm{K}, \mathrm{N}, \mathrm{Zn}, \mathrm{Ca}$ dan $\mathrm{Mg}$ yang dapat meningkatkan hasil pertanian (Kishor et al., 2010). Selain fly ash, kompos kotoran hewan merupakan bahan organik yang dapat digunakan sebagai pembenah tanah. Bahan organik merupakan hasil dekomposisi atau penguraian semua bahan yang berasal dari jaringan tanaman dan hewan. Bahan organik memiliki kemampuan dalam memperbaiki sifat fisik, kimia dan biologi tanah.Kandungan hara makro dalam bahan organik meliputi N, P, K, Ca, Mg dan S dan unsur hara mikro $\mathrm{Zn}, \mathrm{Cu}, \mathrm{Mo}, \mathrm{Co}, \mathrm{B}, \mathrm{Mn}$ dan $\mathrm{Fe}$ yang dapat memperbaiki kondisi di tanah-tanah marginal. Pengunaan bahan organik dapat meningkatkan mikrorganisme tanah dan juga meningkatkan sifat fisik-kimia yaitu tanah $\mathrm{pH}$, total karbon, $\mathrm{P}$ tersedia dan kapasitas tukar kation (Kajian Aktivitas Mikroorganisme Tanah Pada Beberapa Cara Penggunaan Lahan Di Desa Pal IX Kecamatan Sungai Kakap Kabupaten Kuburaya, 2015). Berdasarkan uraian tersebut, penelitian pemanfaatan fly ash yang dikombinasikan dengan kompos kotoran hewan dengan tujuan meningkatkan penggunaan fly ash dan mengurangi dampak lingkungan dari limbah pembakaran batu bara oleh industri.

\section{METODE PENELITIAN}

Penelitian dilaksanakan di rumah kaca STIPER Dharma Wacana Metro dan UPT Laboratorium Terpadu dan Sentra Innovasi Teknologi Universitas Lampung. Penelitian menggunakan Rancangan Acak Kelompok Lengkap yang disusun secara Faktorial. Faktor pertama adalah level dosis fly ash $(\mathrm{F})$ yaitu $\mathrm{f}_{0}=0$ gram/ $\operatorname{pot}(0$ ton $/ \mathrm{ha}), \mathrm{f}_{1}=75 \mathrm{gram} / \operatorname{pot}(50$ ton $/ \mathrm{ha}), \mathrm{f}_{2}=150$ gram/pot $(100$ ton $/$ ha $)$, dan $f_{3}=225 \mathrm{gram} /$ pot $(150$ ton/ha) dan faktor kedua adalah dosis kompos kotoran sapi dengan dua taraf yaitu $\mathrm{c}_{1}=15$ (10 ton/ha), $\mathrm{c}_{2}=30 \mathrm{gram} / \operatorname{pot}(20 \mathrm{ton} / \mathrm{ha})$, dan $\mathrm{c}_{3}=45 \mathrm{gram} / \operatorname{pot}(30$ ton/ha). Media tanam yang digunakan seberat $3 \mathrm{~kg}$ tanah kering. Masing-masing percobaan dilakukan pengulangan sebanyak tiga kali sehingga secara keseluruhan terdapat 36 pot percobaan.

Variabel analisis aktivitas biologi tanah seperti total bakteri, total fungi, respirasi tanah, dilakukan setelah 4 minggu. Analisis data menggunakan sidik ragam (Anava) pada selang kepercayaan 95\%. Perlakuan yang berpengaruh nyata dilakukan uji Beda Nyata Terkecil (BNT) taraf 5\%.

\section{HASIL DAN PEMBAHASAN}

Status biologi tanah melingkupi aktivitas biologis tanah yang terjadi karena adanya aktivitas kehidupan baik organisme dan mikroorganisme dalam suatu massa tanah. Perubahan kimiawi dengan adanya penambahan fly ash ke dalam tanah mempengaruhi terjadinya perubahan komunitas mikroorganisme di lingkungan karena mereka yang pertama kali berhubungan dengan perubahan tersebut. Pada umumnya aktivitas mikroorganisme tanah akan berbanding lurus dengan jumlah total mikroorganisme di dalam tanah yaitu bakteri dan fungi serta organisme lain, jika total mikroorganisme tinggi maka aktivitas mikroorganisme juga semakin tinggi (Priyadi et al., 2018). Mikroorganisme tanah memiliki peranan sangat penting dalam menentukan kelarutan, mobilitas, dan ketersediaan logam bagi tumbuhan dengan mengubah nilai $\mathrm{pH}$ di lingkungan mikro tanah, spesiasi logam, dan mengekskresikan senyawa pengkhelat logam (Geoffrey, 2010).

Penambahan fly ash berkontribusi pada peningkatan jumlah bakteri. Peningkatan jumlah bakteri dimulai pada penambahan fly ash 50 ton/hadan peningkatan tertinggi pada penambahan fly ash 100 ton/ha sebanyak 7,05\% dibanding dengan kontrol (tanpa fly ash). Peningkatan populasi mikroba tersebut berkaitan dengan penambahan fly ash yang memungkinkan adanya pelepasan nutrisi dan perbai- 
kan sifat fisik dan kimia tanah dari fly ash. Efek kimia dan biologi dari perbaikan tanah dengan abu terbang adalah sebagai akibat dari peningkatan mobilitas ion kalsium dan hidroksida karena fluktuasi $\mathrm{pH}$. Penerapan fly ash menunjukkan kecenderungan meningkatkan $\mathrm{pH}$ dan elemen seperti $\mathrm{B}, \mathrm{Mo}, \mathrm{Se}$, dan Al (Sharma \& Kalra, 2006).

Tabel 1. Total bakteri akibat aplikasi limbah fly Ash batu bara

\begin{tabular}{lllll}
\hline \multirow{2}{*}{$\begin{array}{l}\text { Fly Ash } \\
\text { (ton/ha) }\end{array}$} & \multicolumn{3}{c}{ Pupuk Kandang (ton/ha) } & Rata-rata \\
\cline { 2 - 4 } & \multicolumn{1}{c}{10} & \multicolumn{2}{c}{20} & 30 \\
\hline & $1,6 \times 10^{5}$ & $1,7 \times 10^{5}$ & $1,9 \times 10^{5}$ & $1,7 \times 10^{5}$ \\
50 & $2,4 \times 10^{5}$ & $2,6 \times 10^{5}$ & $3,5 \times 10^{5}$ & $2,8 \times 10^{5}$ \\
100 & $12,5 \times 10^{5}$ & $15,3 \times 10^{5}$ & $13,3 \times 10^{5}$ & $13,7 \times 10^{5}$ \\
150 & $3,0 \times 10^{5}$ & $3,1 \times 10^{5}$ & $3,5 \times 10^{5}$ & $3,2 \times 10^{5}$ \\
\hline Rata-rata & $6,5 \times 10^{5}$ & $7,6 \times 10^{5}$ & $7,4 \times 10^{5}$ & \\
\hline
\end{tabular}

Keterangan : Angka yang diikuti huruf yang sama pada kolom yang sama berbeda tidak nyata pada BNT taraf $5 \%$.

Penelitian Surridge et al. (2009) menunjukkan bahwa penambahan fly ash 50 ton/ha memiliki efek pengapuran pada tanah yang menyebabkan peningkatan mobilitas ion kalsium dan hidroksida, yang akhirnya menyebabkan peningkatan keanekaragaman spesies dan jumlah bakteri. Sejalan dengan hal di atas penelitian Arthur et al. (1984) juga menunjukkan bahwa penerapan fly ash hingga 100 ton/ha di tanah berdampak positif pada aktivitas mikroba tanah heterotropik, namun dengan tingkat amandemen yang lebih tinggi (400-700 ton/ha) dapat berdampak negatif pada mikroorganisme tanah. Sementara itu Kohli \& Goyal (2010) melaporkan bahwa penerapan fly ash sebagai amandemen sebesar 10\% optimal untuk populasi bakteri, aktivitas dehidrogenase tanah dan biomassa mikroba.

Jumlah rata-rata bakteri tanah pada perlakuan tanpa aplikasi fly ash adalah $2,75.10^{6} \mathrm{CFU} / \mathrm{g}$ yang meningkat menjadi $11,6 \cdot 10^{6} \mathrm{CFU} / \mathrm{g}$ tanah pada tingkat amandemen fly ash 10\% dan akhirnya turun menjadi $0,43 \mathrm{CFU} / \mathrm{g}$ pada tingkat amandemen fly ash 30\%. Gaind \& Gaur (2004) menemukan bahwa pada aplikasi fly ash, A. chroococcum, A. brasilense dan $B$. circulans menunjukkan kelangsungan hidup yang maksimal sedangkan $P$. striata berkembang biak paling baik pada kombinasi (1:1). Chetstowski et al. (2014) menyatakan bahwa aplikasi fly ash pada tanah dengan dosis 50-800 mg/ha meningkatkan 3 kali populasi bakteri capiotrophic dan Actinomycetes hingga $40 \%$ pada pengamatan awal setelah 21 tahun aplikasi (pengambilan sampel pertama). Pada aplikasi fly ash dosis 150 ton/ha terjadi penghambatan atau penurunan populasi bakteri. Hal ini karena semakin tingginya kandungan logam dan salinitas residu fly ash dibandingkan dengan dosis yang lain. Fly ash juga memiliki kandungan logam berat beracun yang tinggi yang dapat menghambat proses metabolisme mikroba bila ditambahkan ke dalam tanah pada konsentrasi yang lebih tinggi (Page et al., 1979).

Tingginya kandungan logam-logam pada fly ash seperti $\mathrm{Pb}$ memungkinkan juga telah mempengaruhi total bakteri. Galur galur Escherichia coli dan Pseudomonas putida merupakan galur mikroba yang dapat memacu transfonnasi logam berbahaya, seperti $\mathrm{Pb}$ (II), Hg (II), Au (III), Te (IV), dan Ag (I). Bakteri -bakteri pereduksi logam mampu menggunakan berbagai ion-ion logam teroksidasi seperti sebagai akseptor elektron tenninal seperti galur Shewanella putrefaciens yang mereduksi Fe (III) dan Mn (IV) juga mampu mereduksi U (VI) menjadi U (IV) yang berbahaya dan bersifat sangat larut menjadi sukar larut. Bakteri mampu menghasilkan senyawa polimer ekstraseluler (Extracellular Polymeric Substances) yang dikeluarkan dari tubuhnya berupa senyawa organik seperti polisakarida, protein, asam nukleat, dan fosfolipida. (Pal \& Paul, 2008) menyatakan bahwa senyawa polimer ekstraseluler memiliki peranan adhesi antar sel, perlindungan sel dari lingkungan yang mengancamnya, degradasi senyawa pencemar, dan sorpsi logam yang terdapat di sekitar sel.

Eksopolisakarida dan biopolimer lain penyusun senyawa polimer ekstraseluler memiliki kemampuan mengikat logam karena adanya gugus-gugus fungsional bermuatan negatif seperti gugus fosfat, karboksilat, dan uronat. Bakteri dari genus Paenibacillus diketahui menghasilkan senyawa polimer ekstraseluler yang dapat mengikat ion $\mathrm{Cu}^{2+}$, ion-ion $\mathrm{Pb}^{2+}, \mathrm{Cd}^{2+}, \mathrm{Zn}^{2+}$, $\mathrm{Ni}^{2+}$, dan $\mathrm{Co}^{2+}$. Dengan demikian pengaplikasian $f l y$ ash memberikan pengaruh yang sangat bervariasi terhadap pertumbuhan dan perkembangan mahluk hidup yang tergolong mikroorganisme. Hal ini dapat terlihat bahwa pada tanah atau kondisi lingkungan tertentu mempengaruhi jumlah bakteri seperti actinomycetes.

Penambahan bahan organik ke dalam tanah berupa pupuk kandang dapat berperan dalam meningkatkan kesuburan tanah dan memperbaiki sifat fisik, kimia dan biologi tanah Dari penggunaan berbagai dosis pupuk kandang menunjukkan bahwa meskipun secara statistik berbagai dosis 10, 20, 30 ton/ha berbeda tidak nyata terhadap semua peubah yang diamati namun diketahui semakin tinggi dosis pupuk yang diberikan semakin meningkatkan total mikroorganisme total bakteri, fungi, dan respirasi tanah (Tabel 2).

Penambahan amandemen organik seperti pupuk kandang menghasilkan peningkatan biomassa mikroba (bakteri dan jamur tanah) dan aktivitas mikroba yang lebih tinggi. Pupuk kandang kotoran sapi memiliki total fungi lebih tinggi dibanding jumlah bakteri heterotrofik. Bakteri yang diisolasi adalah E. coli, P. aeruginosa, Klebsiella spp., Salmonella spp., Staphylococcus sp., Shigella sp., Serratia $s p$., Sedangkan jamur yang diisolasi adalah $A$. niger, A. flavus, Rhodotorula spp., Rhizopus stolonifer, 
sumber hara tanaman adalah biomassa mikroba tanah, dan sangat berkorelasi dengan karbon organik tanah (Dijkstra et al., 2009).

Tabel 2. Total fungi akibat aplikasi limbah fly ash batu bara

\begin{tabular}{ccccc}
\hline \multirow{2}{*}{$\begin{array}{c}\text { Fly Ash } \\
\text { (ton/ha) }\end{array}$} & \multicolumn{3}{c}{ Pupuk Kandang (ton/ha) } & Rata-rata \\
\cline { 2 - 4 } & 10 & \multicolumn{2}{c}{20} & 30 \\
\hline \multicolumn{5}{c}{ Log CFU/g } \\
0 & $7,2 \times 10^{7}$ & $7,5 \times 10^{7}$ & $10,5 \times 10^{7}$ & $7,5 \times 10^{7} \mathrm{~A}$ \\
50 & $8,0 \times 10^{7}$ & $7,4 \times 10^{7}$ & $9,1 \times 10^{7}$ & $8,1 \times 10^{7} \mathrm{~B}$ \\
100 & $19 \times 10^{7}$ & $17 \times 10^{7}$ & $17,3 \times 10^{7}$ & $17,8 \times 10^{7} \mathrm{C}$ \\
150 & $5,1 \times 10^{7}$ & $4,5 \times 10^{7}$ & $4,3 \times 10^{7}$ & $4,6 \times 10^{7} \mathrm{~A}$ \\
\hline Rata-rata & $9,8 \times 10^{7}$ & $9,1 \times 10^{7}$ & $10,3 \times 10^{7}$ \\
\hline
\end{tabular}

Karbon dan unsur hara lain yang terkandung dalam pupuk kandang dapat meningkatkan biomassa mikroba dan laju respirasi tanah. Penggunaan pupuk kandang meningkatkan kekayaan spesies dan merangsang kelompok mikroba copiotrophic (Alphaproteobacteria, Betaproteobacteria, dan Firmicutes) yang sering terlibat dalam degradasi senyawa organik kompleks (Das et al., 2017). Selain itu, beberapa spesies yang dominan (misalnya: A. zeae, A. halopraeferens, A. rugosum, C. alkalicellulosi, C. caenicola, C. termitidis, C. cellulolyticum, M. magnetotacticum, P. oryza, $P$. comonicomonovasillum, dan fungi pendegradasi lignoselulosa. Hasil penelitian Idham et al. (2016) menunjukkan bahwa hasil isolasi pada pupuk kendang sapi Palu lokal terdapat beberapa jenis pengurai mikroba yaitu Lactobacillus sp, Actinomycetess pub, dan Aspergillus sp.

Aplikasi fly ash berbagai dosis berpengaruh terhadap total fungi (Tabel 2). Penambahan dosis fly ash memberikan pengaruh positif terhadap peningkatan jumlah fungi. Jumlah total fungi pada tanah marginal dengan perlakuan penambahan dosis fly ash hingga 100 ton/ha mampu meningkatkan total fungi $1,37 \%$ dibanding dengan kontrol, namun dosis tertentu yaitu 150 ton/hajustru mampu menurunkan total mikroorganisme fungi. Gaind \& Gaur (2004) mengemukakan bahwa populasi fungi pada penggunaan fly ash yang diinkubasi selama 45 hari dengan komposisi $1: 1$ meningkat yakni mencapai $380 \times 10^{-4} / \mathrm{g}$. Namun penghambatan total fungi terjadi pada penambahan dosis fly ash 150 ton/ha. Penghambatan tersebut mungkin disebabkan oleh tingginya $\mathrm{pH}$, kandungan logam, dan salinitas residu fly ash.

Mikroba tanah berperan sangat penting dalam menentukan kelarutan, mobilitas,dan ketersediaan logam bagi tumbuhan melalui pengubahan $\mathrm{pH}$ di lingkungan mikro tanah, spesiasi logam, dan pengeluaran (excretion) senyawa pengkhelat logam (Anderson \& Domsch, 1993). Selain itu pada penelitian Chetstowski et al. (2014) menunjukkan aplikasi fly ash dengan dosis $400 \mathrm{mg} / \mathrm{ha}$ meningkatkan populasi fungi $139 \%$ dan pada dosis $800 \mathrm{mg} / \mathrm{ha}$ meningkatkan 45\% lebih tinggi dibanding dengan kontrol. Menurut Schutter \& Fuhrmann (2001), bahwa aplikasi abu batubara dosis tinggi, di atas $400 \mathrm{mg} / \mathrm{ha}$, berkontribusi pada peningkatan jumlah jamur flamentosa di tanah.

Analisis komunitas asam lemak menunjukkan peningkatan populasi jamur, termasuk jamur mikoriza arbuskular. Pada penelitian ini tidak diketahui jenis fungi yang diperoleh. Tingginya total fungi yang dapat tumbuh pada lahan tersebut dapat dijadikan indikator bahwa kehidupan mikroorganisme masih berlangsung. Menurut Shrivastava et al. (2018), diketahui bahwa terdapat 9 spesies jamur yang telah diisolasi dari lahan yang terkontaminasi oleh fly ash yang disominasi oleh $A$. niger, $C$. lunata, $P$. chrysogenum, Penicillium sp. and Rhizopus sp. (Makut \& Adeibijola, 2012), menyebutkan bahwa A. niger, A. aculeatus, A. carbonarius C. lunata, P. c5 hrysogenum, Penicillium sp., $T$. viride, dan $R$. stolonifera merupakan spesies fungi yang dapat memperbaiki sifat kimia tanah yang kaya logam termasuk $\mathrm{Pb}$ dan aluminium.

Tabel 3. Respirasi tanah akibat aplikasi limbah fly ash batu bara

\begin{tabular}{ccccc}
\hline \multirow{2}{*}{$\begin{array}{c}\text { Fly Ash } \\
\text { ton/ha) }\end{array}$} & \multicolumn{3}{c}{ Pupuk Kandang (ton $\underline{\underline{h a})}$ Rata-rata } \\
\cline { 2 - 3 } & 10 & 20 & 30 & \\
\hline \multicolumn{5}{c}{$\mathrm{CO}_{2} / \mathrm{mg}$} \\
50 & 27,90 & 30,70 & 30,00 & 29,53 \\
100 & 36,80 & 31,20 & 37,20 & 35,07 \\
150 & 61,60 & 67,20 & 34,80 & 54,53 \\
\hline Rata-rata & 43,20 & 33,60 & 37,00 & 37,93 \\
\hline
\end{tabular}

Aktivitas mikroorganisme tanah tertinggi dalam produksi $\mathrm{CO}_{2}$ terdapat pada penambahan dosis fly ash 100 ton/ha yaitu 54,53 $\mathrm{CO}_{2 / \mathrm{mg}}$ sedangkan produksi $\mathrm{CO}_{2}$ terendah yaitu pada perlakuan kontrol 0 ton/ha yaitu 29,53 $\mathrm{CO}_{2} / \mathrm{mg}$ (Tabel 3). Hal ini menunjukkan bahwa adanya keterlibatan populasi total mikroba baik fungi maupun bakteri dengan produksi $\mathrm{CO}_{2}$. Dapat diketahui bahwa produksi $\mathrm{CO}_{2}$ tertinggi yaitu pada dosis fly ash 100 ton/ha memiliki korelasi positif dengan populasi bakteri dan fungi. Dengan demikian dimungkinkan bahwa sebagian besar peningkatan aktivitas mikroba disebabkan oleh peningkatan populasi bakteri dan fungi. Keseluruhan jumlah mikroorganisme tanah yang tinggi akan menghasilkan $\mathrm{CO}_{2}$ yang tinggi, karena tingginya aktivitas yang dilakukan oleh mikroorganisme tersebut (Wicaksono et al., 2015). Hasil pengukuran $\mathrm{CO}_{2}$ memberikan ukuran aktivitas metabolik spesifik yang bervariasi sesuai dengan komposisi dan keadaan fisio logis komunitas mikroba, ketersediaan substrat, dan 
berbagai faktor abiotik (Anderson \& Domsch, 1993). Sehingga dalam penelitian ini tingkat respirasi menjadi indikator semakin tinggi respirasi maka semakin besar aktivitas mikroba.

Kajian evolusi $\mathrm{CO}_{2}$ dari penggunaan fly ash pada tanah yang diinkubasi selama dua bulan pada kapasitas menahan air 50\%, menunjukkan respirasi tanah dan aktivitas mikroba meningkat hingga 5\%. Penggunaan fly ash dengan 7 konsentrasi $(0,2.5,5$, $10,15,25$ dan $50 \% \mathrm{w} / \mathrm{w})$ diketahui tidak ada hambatan pada respirasi tanah hingga dosis penggunaan fly ash 2,5\% (Pati \& Sahu, 2004). Namun dengan penambahan dosis fly ash lebih lanjut, aktivitas respirasi tanah secara signifikan menjadi menurun. Di sisi lain, respirasi tanah yang meningkat terus pada pengamatan hingga dosis fly ash 5\% bila tanah mengandung cacing tanah.

\section{KESIMPULAN}

Penambahan fly ash pada berbagai dosis dapat mempengaruhi aktivitas biologi tanah yang ditandai dengan adanya peningkatan populasi fungi, bakteri, dan Respirasi tanah. Diketahui populasi mikroorganisme tertinggi fungi yaitu $17,8 \times 10^{7} \mathrm{Log} \mathrm{CFU} / \mathrm{g}$, bakteri $13,7 \times 10^{5} \mathrm{Log} \mathrm{CFU} / \mathrm{g}$ sedangkan rataan tertinggi respirasi tanah yaitu $54,53 \mathrm{mg} \mathrm{CO} 2$ pada dosis fly ash 100 ton/ha. Selain itu pada pemberian berbagai dosis kompos kotoran sapi 10, 20, 30 ton/ha relatif sama pada peubah yang diamati.

\section{SANWACANA}

Ucapan terima kasih disampaikan kepada Kementerian Riset, Teknologi, dan Pendidikan Tinggi yang telah mendanai penelitian ini melalui skema Penelitian Dosen Pemula Tahun 2019.

\section{DAFTAR PUSTAKA}

Aggarwal, S., Singh, G. R. \& Yadav, B. R. (2009). Utilization of fly ash for crop production: effect on the growth of wheat and sorghum crops and soil properties. Journal of Agricultural Physics, 9, 20-23.

Anderson, T. \& Domsch, K. . (1993). The metabolic quotient for $\mathrm{CO}_{2}\left(\mathrm{q} \mathrm{CO}_{2}\right)$ as a specific activity parameter to assess the effects of environmental conditions, such as ph, on the microbial biomass of forest soils. Soil Biology and Biochemistry, 25(3), 393-395.

Arthur, M. F., Zwick, T. C., Tolle, D. A. \& Voris, P. Van. (1984). Effects of fly ash on microbial $\mathrm{C}_{2}$ evolution from an agricultural soil. 22, 209-211.

Basu, M., Pande, M., Bhadoria, P. B. S. \& Mahapatra, S. C. (2009). Potential fly-ash utilization in agriculture: A global review. Progress in Natural
Science,19(10),1173-1186.DOI:https://doi.org/ 10.1016/j.pnsc.2008.12.006.

Chetstowski, A., Chieko, Z. \& Borowik, A. (2014). Effect of coal ash on the microbial and enzymatic activity in soil. Agroekologia-Artyku, 2, 32-36.

Das, S., Jeong, S. T., Das, S., Kim, P. J. \& Norton, J. M. (2017). Composted cattle manure increases microbial activity and soil fertility more than composted swine manure in a submerged rice paddy. Front. Microbiol, 8, 1-10. DOI:https:// doi.org/10.3389/fmicb.2017.01702.

Dijkstra, F. A., Bader, N. E., Johnson, D. W. \& Cheng, W. (2009). Soil biology \& biochemistry does accelerated soil organic matter decomposition in the presence of plants increase plant $\mathrm{N}$ availability?. Soil Biology and Biochemistry, 41 (6), 1080-1087. DOI: https://doi.org/10.1016/ j.soilbio.2009.02.013.

Gaind, S. \& Gaur, A. C. (2004). Evaluation of fly ash as a carrier for diazotrophs and phosphobacteria Bioresource Technology, 95(2), 187-190. DOI: https://doi.org/10.1016/j.biortech.2003.07.014.

Geoffrey, M. . (2010). Metals, minerals and microbes: geomicrobiology and bioremediation. Microbiology, 156, 609-643. DOI : https:// doi.org/10.1099/mic.0.037143-0.

Idham, Sudiarso, Aini, N. \& Nuraini, Y. (2016). Isolation and identification on microorganism decomposers of Palu local cow manure of Central Sulawesi, Indonesia. J.Degrade.Min. Land Manage, 3(4), 625-629. DOI: https://doi.org/10.15243/ jdmlm.2016.034.625.

Kementrian LHK. (2020). Peraturan Menteri Penyimpanan Limbah Bahan Berbahaya Dan Beracun. 1-52. http://jdih.menlhk.co.id/uploads/ files/P_12_2020_ PENYIMPANAN_LIMBAH_ B3_menlhk_06262020092441.pdf

Kishor, P., Ghosh, A. \& Kumar, D. (2010). Use of flyash in agriculturae: a way to improve soil fertility and its productivity. Asian Journal of Agricultural Research, 4(1), 1-14.

Kohli, S. \& Goyal, D. (2010). Effect of fly ash application on some soil physical properties and microbial activities. Acta Agrophysica, 16(2), 327 -335 .

Makut, M. \& Ade-ibijola, O. (2012). Citric acid producing fungi found in the soil environment of Keffi metropolis, Nasarawa State. International Research Journal of Microbiology, 3(7), 240245.

Page, A., Elseewi, A. A. \& Straughan, I. R. (1979). Physical and chemical properties of fly ash from coal-fired power plants with reference to environmental impacts. Residue Reviews, 71, 83-120.

Pal, A. \& Paul, A. K. (2008). Microbial extracellular polymeric substances: central elements in 
heavy metal bioremediation. Indian J Microbiol, 48, 49-64.

Pati, S. S. \& Sahu, S. K. (2004). $\mathrm{CO}_{2}$ evolution and enzyme activities (dehydrogenase, protease and amylase) of fly ash amended soil in the presence and absence of earthworms (Drawida willsi Michaelsen) under laboratory conditions. Geoderma, 118, 289-301.

Priyadi, Kurniawati, N. \& Nugroho, P. (2018). Aktivitas biologi tanah yang berasal dari perkebunan karet pada berbagai kondisi kelengasan. EnviScience, 2 (1), 10-15.

Schutter, M. \& Fuhrmann, J. (2001). Soil microbial community responses to fly ash amendment as revealed by analyses of whole soils and bacterial isolates. Soil Biology and Biochemistry, 33 (14), 1947-1958.

Sharma, S. K. \& Kalra, N. (2006). Effect of flyash incorporation on soil properties and productiv- ity of crops : A review aspects of flyash for its application in agriculture. Journal of Scientific \& Industrial Research, 65(5), 383-390.

Shrivastava, H., Mahish, P.K Anjali, G. (2018). Effect of industrial fly ash on the growth of some crop field soil fungi adapted with ash content. International Journal of Agriculture, Environment and Biotechnology, 11(1), 203-207.

Surridge, A.K., van der Merwe, A. \& Kruger, R. (2009). Preliminary microbial studies on the impact of plants and South African fly ash on amelioration of crude oil polluted acid soils . World of Coal Ash (WOCA) Conference, 1.

Wicaksono, T., Sagiman, S. \& Umran, I. (2015). Kajian Aktivitas Mikroorganisme Tanah Pada Beberapa Cara Penggunaan Lahan di Desa Pal IX Kecamatan Sungai Kakap Kabupaten Kuburaya 